\title{
Economic Growth in the Axis of Human Capital, R\&D and Innovation: An Analysis on the G8 Countries
}

\author{
Ph.D. Candidate Mustafa Gömleksiz (Necmettin Erbakan University, Turkey) \\ Assoc. Prof. Dr. Birol Mercan (Necmettin Erbakan University, Turkey)
}

\begin{abstract}
In recent years, human capital, $R \& D$ activities and innovation have an important place in both empirical studies related with economic growth and new growth models. In this context, it is drawn that innovations frequently arising from R\&D activities are the main engine of the new economy, while productivity-based positive relationship between human capital and economic growth of the countries is emphasized by a variety of evidence. This paper empirically investigates the impact of human capital, R\&D and innovation on economic growth in context of G8 countries. Indicators used in analyze covering the period 1998-2012 are gross domestic product per capita, public spending on education, population with tertiary education between aged 25-64, total public and private sector R\&D expenditures and international patent grants. Such relationships were analyzed by using the panel data method for the 8 cross-sectional units and 15 year long period. The results indicate that impact of both human capital and innovation on economic growth is signifanctly positive. Furthermore, results show that the total public and private sector R\&D expenditure has a negative effect on economic growth while its coefficient statistically insignificant. Latter result obtained from analyze also contribute to discussions about the roles of patents and public funding or public performed R\&D in economic growth.
\end{abstract}

\section{Introduction}

In recent years, human capital, R\&D activities and innovation have an important place in various empirical studies (Teixeira and Fortuna, 2004; Canton, et. al, 2005; Batabyal and Nijkamp, 2013; Akinwale, et. al, 2012; Vogel, 2012; Jean, 2012; Cinnirella and Streb, 2013) conducted in both regional and national levels related with economic growth. In this studies, it is mostly drawn that innovations frequently arising from R\&D activities is the main engine of the new economy while productivity-based positive relationship between human capital and economic growth of the countries is emphasized. However, new growth models with endogenous human capital, R\&D, and innovation (Romer, 1986; Lucas, 1988; Aghion and Howitt, 1992) have underlined the vital role of these inputs in enhancing the economic growth.

According to recent contributions to growth literature, economists have argued that long run economic growth of nations is determined by economic behaviors such as R\&D intensity, innovations, and human actions such as educational attainment (Canton, et. al, 2005: 1). Among them, human actions, in other words human capital, might affect the growth in two ways. First, human capital can enhance total factor productivity directly as skilled labor. Second, human capital might induce technological activities of firms by innovations, imitations or adoption of new technologies (Romer, 1990; Benhabib and Spiegel, 1994; Teixeira and Fortuna, 2004; Cinnirella and Streb, 2013). Furthermore, in their Schumpeterian endogenous growth model Aghion and Howitt (1992) showed that R\&D activities can lead innovations which give firms a monopoly power by patent law and thus economic growth can be determined by technological innovations in a Schumpeterian creative destruction process.

The function of innovation in growth is to spread novelties in economic environment. If somewhat, the flow of innovation is interrupted, the long term growth rate of the economy will be low or it will be entered into a steady state where there is no growth. Thus, innovations is vital for long term economic growth (Fagerberg, 2005: 1920). The sources of innovation may be either internal or external to the firm. Innovations can either be embodied in capital goods and products or disembodied such as patents, licences, design or R\&D activities (Archibugi and Pianta, 1996: 451). In most of empirical studies innovation performance has been approximated by two proxies: the number of patent applications and patent grants (OECD, 1994; Archibugi and Pianta, 1996; Brenner and Broekel, 2011; Slaper, et. al, 2011; Hollanders and Tarantola, 2011). A patent can improve efficiency of the economy by means of providing the incentive for firms to engage in research, fostering innovation, hence growth and value creation. However, a central dilemma created by patents: they might interrupt static efficiency of the growth by reducing competition (in a state of monopoly) and thus higher prices (OECD, 2009: 22; Vogel, 2012: $5)$. Also, in context of supporting innovation, there is some controversy among economists about R\&D activities performed by public sector and public funds to these activities (Klette, et. al, 2000; Martin and Scott, 2000).

This paper empirically investigates the impact of human capital, R\&D and innovation on economic growth in context of G8 countries. Indicators used in analyze covering the period 1998-2012 related to economic growth, human capital, R\&D and innovation are gross domestic product per capita, public spending on education, population with tertiary education between aged 25-64, total public and private sector R\&D expenditures and international patent grants respectively. Section two focuses on the literature review about empirical studies, 
while methodology and definitions are discussed in section three. Section four presents results of the data analysis and the last section concludes the paper.

\section{Literature Review}

In recent literature conducted by economists and researchers, there is much concern about new sources of economic growth. The majority of this literature investigates the effects of human capital, R\&D activities by public and private sectors, and innovation in explaining changes in total factor productivity, and thus economic growth.

Barro (1991) examined 98 countries for the period 1960-1985. In his study, results showed that the growth rate of real per capita GDP is positively related to initial human capital (proxied by 1960 school- enrollment rates) and negatively related to the initial (1960) level of real per capita GDP. In their cross-country empirical study which covers 78 countries and the period 1960-1985, Benhabib and Spiegel (1994) indicated that human capital affects growth through two mechanisms. Accordingly, human capital levels directly influence both the rate of domestically produced technological innovation, and the speed of adoption of technology from abroad. Furthermore, Bassanini and Scarpetta (2001) and Krueger and Lindahl (2001) investigate the relationship between education level, human capital and economic growth in their cross-country studies. Both of the results showed that the changes in education and human capital accumulation positively affect economic growth.

Griffith, et. al, (2001) explored the roles of R\&D activities and human capital in total factor productivity growth. In the analysis of their sample which consists of a panel of twelve OECD countries over the period 1974-1990, it is found that R\&D and human capital play an important role in productivity growth and countries' catch up process as well as stimulating innovation directly. Another study conducted by Bilbao-Osorio and Rodríguez-Pose (2004) concentrated on selected NUTS1 and NUTS2 regions in the European Union. The results of the study emphasized the complex relationship between R\&D investment, innovation, and economic growth.

Akinwale, et. al, (2012) focused the impact of R\&D and innovation, labor and capital on economic growth in Nigeria. The results of the study using gross fixed capital formation, labor force and gross expenditure on $R \& D$ (GERD) and innovation showed that GERD plays a significant role on economic growth but an inverse coefficient is also observed between them. Researchers implied that low increase in R\&D spending and innovation might refer weak institutions, high corruption practices, low interaction between the academia and the industry, poor coordination system, among others in the country. Also it is shown that labor has significantly positive impact on economic growth.

Vogel (2012) examined the effects of $R \& D$ and human capital on total factor productivity growth in the manufacturing sector across 159 regions of the EU-15 from 1992 to 2005 . His empirical results provide significant evidence of a positive direct effect of human capital and a positive indirect effect of R\&D activity on total factor productivity growth for the EU-15 regions. Another study was conducted by Jean (2012) to test the impact of R\&D and human capital on regional growth in France. The analysis indicates that labor productivity in the French regions is influenced by physical capital, human capital and the intensity in the employment of professionals specialized in R\&D. Moreover, differences in the public and private sources of research funding didn't seem to cause significant differences in the long term growth.

Teixeira and Fortuna (2004) estimated a long run relationship between total factor productivity, human capital stock, internal innovation capability (internal stock of knowledge - measured by the real accumulated expenditures on firms R\&D), and absorption capability within Portuguese. Their results showed that human capital stock is more important than internal innovation capability to explain the Portuguese productivity for the period 1960-1991. Also, human capital and internal innovation capability directly affect Portuguese economy by means of productivity growth and its relation with innovation efforts.

\section{Method and Dataset}

For the analysis of the relationship between economic growth and human capital, R\&D and innovations, a panel data set covering eight countries (U.S., Japan, Germany, England, France, Italy, Canada and Russia) and the period 1998-2012 is conducted. A panel data set contains repeated observations over the same units collected over number of periods. Although panel data are typically collected at the micro-economic level, it has become more and more practice to pool individual time series of a number of countries or industries and analyze them simultaneously (Verbeek, 2004: 341). Thus, while the studies based on cross-sectional data present only differences between same units, studies using panel data can show changes in both cross-section and time units (Baltagi, 2001: 7).

It can be said that there are two types of model to estimate with panel data: fixed effects model and random effects model. The general equation for the fixed effects model is given below:

$$
y_{i t}=\alpha_{i}+\beta_{1} X_{i t}+u_{i t}
$$


In equation (1), where $y_{i t}$ is the dependent variable for each $\mathrm{i}=$ entity and $\mathrm{t}=\mathrm{time}, X_{i t}$ represents one independent variable and $\beta_{1}$ is the coefficient for $\beta_{1}, \alpha_{i}(\mathrm{i}=1 \ldots \mathrm{n})$ is the unknown intercept for each entity and $u_{i t}$ is the error term. In a fixed effects model, if the unobserved variable does not change over time, then any changes in the dependent variable must be due to influences other than these fixed characteristics (Stock and Watson, 2007: 289-290).

The random effects approach assumes that the intercepts of the individuals are different but that they can be treated as drawings from a distribution with mean $\mu$ and variance $\sigma_{\alpha}^{2}$. The essential assumption here is that these drawings are independent of the explanatory variables in $X_{i t}$. This leads to the random effects model, where the individual effects $\alpha_{i}$ are treated as random. The error term in this model consists of two components: a timeinvariant component $\alpha_{i}$ and a remainder component $u_{i t}$ that is uncorrelated over time (Verbeek, 2004: 343). It can be written as:

$$
y_{i t}=\mu+\beta_{1} X_{i t}+\alpha_{i}+u_{i t}
$$

The analysis uses the various databases provided by World Bank, European Statistics Office, OECD, UNESCO, WIPO and national statistical offices. The selection of variables used in model is based on indicators which are frequently encountered in the literature. Accordingly, the selected variables as measurements of economic growth, human capital, R\&D and innovation are gross domestic product per capita, public spendings on education, population with tertiary education between aged $25-64$, total public and private sectors $R \& D$ expenditures and international patent grants respectively. Definitions related to the variables are listed below:

\begin{tabular}{|c|c|c|}
\hline Variable / Indicator & Label & \multirow{6}{*}{$\begin{array}{c}\text { Data Source } \\
\text { - World Bank } \\
\text { (World Development Indicators) } \\
\text { - European Statistics Office } \\
\text { (Eurostat) } \\
\text { - Organization for Economic Co- } \\
\text { operation and Development (OECD } \\
\text { Statistics) } \\
\text { - United Nations Educational, } \\
\text { Scientific and Cultural Organization } \\
\text { (UNESCO) } \\
\text { - World Intellectual Property } \\
\text { Organization (WIPO) } \\
\text { - National statistical offices }\end{array}$} \\
\hline $\begin{array}{l}\text { Gross domestic product per capita } \\
\text { (Current prices/ US Dollars) }\end{array}$ & $G D P$ & \\
\hline Total public spending on education ( $\%$ of GDP) & $E D S$ & \\
\hline $\begin{array}{l}\text { Population with tertiary education } \\
\text { (between aged } 25-64, \% \text { of total population) }\end{array}$ & $H U M$ & \\
\hline $\begin{array}{l}\text { Total research and development expenditure by } \\
\text { public and private sectors } \\
\text { (current and capital expenditures/\% of GDP) }\end{array}$ & $R D E$ & \\
\hline $\begin{array}{l}\text { Direct and The Patent Cooperation Treaty } \\
\text { (PCT) patent grants (total) }\end{array}$ & $P A T$ & \\
\hline
\end{tabular}

Table 1. Selected Variables, Definitions and Data Sources

Analysis using larger population of individual units, and a random effects framework seems appropriate, the fixed effects estimator may be preferred. The reason for this is that it may be the case that $\alpha_{i}$ and $x_{i t}$ are correlated, in which case the random effects approach, ignoring this correlation, leads to inconsistent estimators. The problem of correlation between the individual effects $\alpha_{i}$ and the explanatory variables in $x_{i t}$ can be handled by using the fixed effects approach, which essentially eliminates the $\alpha_{i}$ from the model, and thus eliminates any problems that they may cause. Hausman test suggests a test for the null hypothesis that $x_{i t}$ and $\alpha_{i}$ are uncorrelated. The general idea of a Hausman test is that two estimators are compared: one which is consistent under both the null and alternative hypothesis and one which is consistent under the null hypothesis only (Verbeek, 2004: 351-352).

\begin{tabular}{lccl}
\hline \multicolumn{4}{l}{ Test Cross-Section Random Effects } \\
\hline \hline Test Summary & Chi-Sq. Statistics & Chi-Sq. d.f. & Prob. \\
\hline \hline Cross-Section Random & 28.004 & 4 & 0.000 \\
\hline
\end{tabular}

Table 2. Correlated Random Effects - Hausman Test

When we computed Hausman test (Table.2), the test statistic [Chi-square (4): 28.004, p: 0.00], concluded that null hypothesis (error terms are not correlated with the explanatory variables) is rejected at $1 \%$ significance level. Thus the fixed effects model was preferred in analysis. Also, in analysis we used a logaritmic specification, except variables expressed as percentage. This specification might enable an easier interpretation of estimation and a less sensitivity to outliers. Such equation takes shape the following form:

$$
\ln G D P=\alpha_{i}+\beta_{1} \ln E D S_{i t}+\beta_{2} \ln H U M_{i t}+\beta_{3} \ln R D E_{i t}+\beta_{4} P A T_{i t}+u_{i t}
$$




\section{Findings}

The results from the fixed effects model estimation indicate that approximately $90 \%$ of the changes in economic growth can be attributed to EDS, HUM, RDE, and PAT. Also, F-statistic (p value:0.000), show that at least some of the independent variables explain economic growth at 5\% level of significance. When we look at coefficients of variables, it is observed that EDS, HUM, and PAT each have significantly (at $1 \%$ level of signifance) positive signs while coefficient of RDE is insignificantly negative. This implies that $1 \%$ increase in EDS leads to a \%2.4 increase in GDP. This case means that G8 economies grow faster by means of increasing education spending within the framework of investment in human capital. Also it is shown that stock of human capital in developed countries plays an important role in economic activities. Hereby, estimation results show that a $1 \%$ increase in HUM leads to approximately a \%1.25 increase in GDP. When we look at effect of PAT as a commercial output of innovation, it is seen that patents have a significant impact on economic growth. This result also refers that a well organized patent system in national and international context stimulate the economic activities by the way of supporting and rewarding inventors as well as promoting human resources.

\begin{tabular}{|c|c|c|c|c|}
\hline \multicolumn{2}{|c|}{$\begin{array}{l}\text { Dependent Variable } \\
\text { Sample } \\
\text { Observations }\end{array}$} & $\begin{array}{l}\ln \mathrm{GDP} \\
1998: 2012 \\
120 \\
\end{array}$ & \multirow[b]{2}{*}{ t-statistic } & \multirow[b]{2}{*}{ Prob. } \\
\hline Variable & Coefficient & Std. Error & & \\
\hline $\mathrm{C}$ & -1.403 & 1.111 & -1.262 & 0.209 \\
\hline $\ln \mathrm{EDS}$ & 2.409 & 0.331 & 7.258 & 0.000 \\
\hline $\ln \mathrm{HUM}$ & 1.259 & 0.254 & 4.942 & 0.000 \\
\hline $\ln \mathrm{RDE}$ & -0.646 & 0.474 & -1.363 & 0.175 \\
\hline $\ln \mathrm{PAT}$ & 0.394 & 0.095 & 4.111 & 0.000 \\
\hline \multicolumn{2}{|c|}{ Fixed Effects (Cross) } & & & \\
\hline _US & -0.777 & & & \\
\hline _Japan & 0.278 & & & \\
\hline _Germany & 0.841 & & & \\
\hline _England & 0.344 & & & \\
\hline _France & 0.301 & & & \\
\hline Italy & 1.468 & & & \\
\hline _Canada & -0.351 & & & \\
\hline _Russia & -2.103 & & & \\
\hline \multicolumn{2}{|c|}{ R-squared } & 0.902 & & \\
\hline \multicolumn{2}{|c|}{ Adjusted R-squared } & 0.892 & & \\
\hline \multicolumn{2}{|c|}{ F-statistic } & 90.794 & & \\
\hline \multicolumn{2}{|c|}{ Prob(F-statistic) } & 0.000 & & \\
\hline
\end{tabular}

Table 3. Results of Fixed Effects Model Estimation

The p-value of RDE is 0.175 , which represent that R\&D expenditure as a sum of public and private sector expenditures statistically do not have a significant impact on growth while its coefficient is negative. As stated by Klette, et. al (2000) and Bilbao-Osorio and Rodríguez-Pose (2004), this might be a result of governments' design of support mechanism or differences arising from orientation and application of basic research. In this context, the basic research performed by public and higher education, in fact, tends to be less applied and have a low effect on patenting activities. Besides, privately funded research is frequently more effective and tends to have a high commercial returns. Also it can be argued that supported research projects by public funds might cause relatively low productivity levels and inadequate returns to economy (Klette, et. al, 2000; Bilbao-Osorio and Rodríguez-Pose, 2004).

\section{Conclusion}

In this study, roles of human capital, $R \& D$, and innovation in economic growth have been investigated across G8 countries, over the 1998-2012 period. We used data of population with tertiary education between aged 25-64 and total public spending on education as a proxy of human capital. Moreover, as the measurements of R\&D and innovation, we used data for total research and development expenditure by public and private sectors and direct and PCT patent grants respectively. The relationship between the independent variables and economic growth was analyzed using panel data method which enables to pool individual time series of a number of countries or industries and to analyze them simultaneously.

The results from analysis partially confirm previous studies which explored effects of human capital, R\&D, and innovation on economic growth individually or together. Accordingly, the results point to a poisitive and significant effect of human capital and innovation to growth of gross domestic product per capita. Conversely, findings show that the total public and private sector R\&D expenditure has insignificantly negative impact on 
economic growth. Possible reasons of this result is that publicly performed R\&D activities might base on basic research and might have some difficulties arising from commercialization process of inventions. The latter is might be related to lower returns to economy within public funding to private sector. In line with this result, one might also willing to investigate same country group whether it would be more appropriate to separate R\&D expenditures as public sector and private sector.

\section{References}

- Aghion and Howitt, 1992. "A model of growth through creative destruction", Econometrica, 60(2), p. $323-$ 351.

- Akinwale, et. al, 2012. "Understanding the Nexus of R\&D, Innovation and Economic Growth in Nigeria", International Business Research, 5(11), p. 187-196.

- Archibugi and Pianta, 1996. "Measuring Technological Change through Patents and Innovation Surveys", Technovation, 16(9), p. 451-468.

- Baltagi, 2001. Econometric Analysis of Panel Data. John Wiley, New York.

- Barro, 1991. "Economic growth in a cross-section of countries", Quarterly Journal of Economics, 106(2), p. 407-443.

- Batabyal and Nijkamp, 2013. "Human capital use, innovation, patent protection, and economic growth in multiple regions", Economics of Innovation and New Technology, 22(2), p. 113-126.

- Bassanini and Scarpetta, 2001. Does Human Capital Matter for Growth in OECD Countries? Evidence from Pooled Mean-Group Estimates, http://www.oecd.org/eco/labour/1891391.pdf

- Benhabib and Spiegel, 1994. "The role of human capital in economic development: evidence from aggregate cross-country data", Journal of Monetary Economics, 34, p. 143-173.

- Bilbao-Osorio and Rodríguez-Pose, 2004. "From R\&D to Innovation and Economic Growth in the EU", Growth and Change, 35(4), p. 434-455.

- Brenner and Broekel, 2011. "Methodogical Issues in Measuring Innovation Performance of Spatial Units" Industry and Innovation, 18(1), 7-37.

- Canton, et. al, 2005. Human Capital, R\&D and Competition in Macroeconomic Analysis, http://www.enepri.org/files/Publications/WP038.pdf

- Cinnirella and Streb, 2013. The Role of Human Capital and Innovation in Prussian Economic Development, http://www.cesifo-group.de/portal/page/portal/DocBase_Content/WP/WP-CESifo_Working_Papers/wpcesifo-2013/wp-cesifo-2013-09/cesifo1_wp4391.pdf

- Fagerberg, 2005. Introduction. (Editor: Jan Fagerberg, David C. Mowery, Richard R. Nelson). The Oxford Handbook of Innovation. Oxford University Press, New York.

- Griffith, et. al, 2001. Mapping the Two Faces of R\&D: Productivity Growth in a Panel of OECD Industries, http://dx.doi.org/10.1920/wp.ifs.2000.0002.

- Hollanders and Tarantola, 2011. Innovation Union Scoreboard 2010 - Methodology report, http://ec.europa.eu/enterprise/policies/innovation/files/ius-methodology-report_en.pdf

- Jean, 2012. Human Capital And R\&D Driven Growth: Analyze for France at Regional Level on The Long Run, http://thema.univ-fcomte.fr/2012.asrdlf_com/envoitextefinal/auteur/textedef/274.pdf

- Klette, Møen and Griliches, 2000. "Do subsidies to commercial R\&D reduce market failures? Microeconometric evaluation studies", Research Policy, 29, p. 471-495.

- Krueger and Lindahl, 2001. "Education for Growth: Why and For Whom?" Journal of Economic Literature, 39 , p. 1101-1136.

- Lucas, 1988. "On The Mechanics of Economic Development", Journal of Monetary Economics, 22, p. 3-42.

- Martin and Scott, 2000. "The nature of innovation market failure and the design of public support for private innovation”, Research Policy, 29, 437-447.

- OECD, 1994. The Measurement of Scientific and Technological Activities Using Patent Data as Science and Technology Indicators: Patent Manual. OECD Publishing, Paris.

- OECD, 2009.OECD Patent Statistics Manual, http://browse.oecdbookshop.org/oecd/pdfs/free/9209021e.pdf

- Romer, 1986. "Increasing returns and long-run growth", Journal of Political Economy, 94(5), p. 1002-1037.

- Romer, 1990. "Endogenous technological change", Journal of Political Economy, 98(5), p. 71-101.

- Slaper, et. al, 2011. "The Index of Innovation: A New Tool for Regional Analysis", Economic Development Quarterly, 25(1), p. 36-53.

- Stock and Watson, 2007. Introduction to Econometrics (2nd edition). Pearson Addison Wesley, Boston.

- Teixeira and Fortuna, 2003. "Human capital, innovation capability and economic growth in Portugal, 1960 2001", Port Econ J, 3, p. 205-225.

- Verbeek, 2004. A Guide to Modern Econometrics (2nd edition). John Wiley \& Sons, Ltd, West Sussex.

- Vogel, 2012. The Two Faces of R\&D and Human Capital: Evidence from Western European Regions, http://www.economics.ox.ac.uk/materials/working_papers/paper599.pdf 